\title{
Information Technology Infrastructures and Knowledge Management: Towards Organizational Excellence
}

\author{
Nour-Mohammad Yaghoubi (PhD) \\ University of Sistan and Baluchestan \\ School of Management and Accounting \\ Department of Management, Zahedan, Iran \\ E-mail: yaghoobinor@yahoo.com \\ Badroddin Oraee Yazdani (PhD) \\ University of Sistan and Baluchestan \\ School of Management and Accounting \\ Department of Management, Zahedan, Iran \\ Nasir Ahoorani (Corresponding Author) \\ Departement of Industrial Engineering \\ Islamic Azad University, Zahedan Branch \\ Zahedan, Iran \\ E-mail: nasir_ahoorani@yahoo.com \\ Seyyed Ali Banihashemi \\ Departement of Industrial Engineering \\ Young Researchers Club \\ Islamic Azad University, Zahedan Branch, Iran \\ E-mail: a.banihashemi@iauzah.ac.ir
}

Received: June 20, 2011

Accepted: July 7, 2011

doi:10.5539/cis.v4n5p20

\begin{abstract}
Knowledge management is regarded as one of the most fascinating and controversial subjects of business management; and its application scope is extending in the same way as other fields of management. Nonaka and Takochi (1995) proposed a model which resulted in novel transformation in knowledge management. Though the subsequent complementary studies and investigations enriched the concept, but the same trend is still maintaining. Many organizations seeking for establishment of knowledge management have taken the measures for extensive investments in information technology. The purpose of this research is to investigate the role of information technology infrastructures (network and human resources) in establishment of knowledge management (knowledge creation (generation), knowledge sharing (transfer), and knowledge application) in Communications Company of Sistan \& Baluchestan Province. This study is classified as an applied research regarding the objective; and its methodology is descriptive-survey approach. The statistical society includes all the employees of Communications Company of Sistan \& Baluchestan Province. The results obtained from the data analysis imply existence of relations between the variables.
\end{abstract}

Keywords: Knowledge management, Information technology, Network

\section{Introduction}

Considering the continuous changes and progressive development of information technology science and advent of new phenomena and applicable facilities in different segments of organizations, the managers are supposed to 
be capable of identifying the new developments and their application methods for enhancement of work efficiency in their organization. Knowledge generation is not the most essential challenge in knowledge management but possession and distribution of knowledge is the most problematic task. Indeed, non-distributed knowledge has a very low value for the organizations.

Face-to-face dialogues were the traditional methods for knowledge creation and distribution. However, the conventional methods are very slow an ineffective today due to globalization of organizations and companies as well as development of virtual networks. Thus, technology must be necessarily applied for knowledge circulation. One of the most principal difficulties in knowledge management is the precise comprehension of knowledge concept. Generally speaking, knowledge is the information a person holds in his/her mind. Another serious challenge is organizing the experiences and ideas of employees in an applicable manner for others. Definitely, knowledge subject will be the inseparable part of all organization complexes within the subsequent years, and the successful organizations are those which provide the required infrastructure and design the appropriate framework for its implementation. In organizations such as Communications Company, it is asserted that employees are able to present a desirable performance due to having professional knowledge and special skills. This organization is essentially required to provide modern services compatible with progresses in global knowledge due to its international area of activity, relations with universal organizations, necessity for observing the global and specific standards as well as needing to be updated.

In addition to academic experts, other individuals having technical and alternative specialties in different areas have not been yet identified. They can be only benefited from in when problems or technical defects occur in the system or technological equipments, and even sometimes, their knowledge and expertise can never be applied because of remaining unidentified. Despite spending large expenditures by the company for training special skills besides the personal time and capital devoted to learn these abilities, this knowledge may exit from the system via transfer, demise, dismissing and/or retirement of these employees. This happens mainly due to lack of a knowledge-based system to identify the resources accurately. The recovery of this knowledge requires spending time and expenditures again. This research is intended to investigate and appreciate the role of information technology infrastructures in establishment of knowledge management and also in creation of the situation for applying it perfectly in the organization. This study can result in better insight and comprehension of information technology concept, knowledge management, its establishment, and other related subjects. Therefore, the researcher's goals from conducting this research can be listed as follows:

1) Investigating the level of relation between network and knowledge creation in Communications Company of Sistan \& Baluchestan Province.

2) Investigating the level of relation between human resources and knowledge creation in Communications Company of Sistan \& Baluchestan Province.

3) Investigating the level of relation between network and knowledge sharing in Communications Company of Sistan \& Baluchestan Province.

4) Investigating the level of relation between human resources and knowledge sharing in Communications Company of Sistan \& Baluchestan Province.

5) Investigating the level of relation between network and knowledge application in Communications Company of Sistan \& Baluchestan Province.

6) Investigating the level of relation between human resources and knowledge application in Communications Company of Sistan \& Baluchestan Province.

\section{Literature Review}

\subsection{Definition of knowledge management}

Literature relating to knowledge management is shows different standpoints. Progressive organizations of the modern time have realized the significance of knowledge management strategies and tools, therefore, the creation, management and sharing of knowledge is at the top of agenda (Coakes, Amar and Granados, 2010). Knowledge management or knowledge sharing is all about the creation and the transfer of knowledge (McInerney, 2002). It has been reported that potential for knowledge sharing in developing world is higher than the rest of the part (Voelpel and Han, 2005).

But still organizations are in search of ways to facilitate and direct employees towards knowledge sharing. As Cruz, Pe'rez, and Cantero (2009) stated that employees more actively transfer their knowledge when they feel that their organization values them by providing favorable working conditions for their personal and professional growth. The study of Hauschild, Licht, and Stein (2001) argued that the most important knowledge of the organization is always implanted in the minds of its employees. Because this embedded knowledge is more 
personalized in nature. Therefore, what motivates them in sharing this knowledge is very important to explore (Hauschild, Licht and Stein, 2001; Amar, 2004). Singh (2008) conducted a study to know the impact of various leadership styles on tendency to share knowledge among employees and found that the best leadership style to motivate employees towards sharing their knowledge is delegating style which comprises delegation of power, authority, and responsibility to experiment and innovate with information. Employees' commitment also play big role to enhance knowledge sharing motivation therefore, measures should be taken to increase employee commitment so that knowledge sharing activities would be flourished (Hislop, 2003). Establishing virtual communities for knowledge sharing can also help in order to convert knowledge into value creation or innovation (Voelpel and Han, 2005).

Knowledge is not easily measured or audited, so organizations must manage knowledge effectively in order to take full advantage of the skills and experience inherent in their systems and structures as well as the tacit knowledge belonging to the employees of the firm. Prior studies defining knowledge management are shown in Table 1. Knowledge management is a managerial activity which develops, transfers, transmits, stores and applies knowledge, as well as providing the members of the organization with real information to react and make the right decisions, in order to attain the organization's goals.

\subsection{Knowledge Management System}

Knowledge management (KM) is a process that helps organizations identify, select, organize, disseminate, and transfer important information and expertise that are part of the organization's memory and that typically reside within the organization in an unstructured manner. This structuring of knowledge enables effective and efficient problem solving, dynamic learning, strategic planning, and decision making. Knowledge management initiatives focus on identifying knowledge, explicating it in such a way that it can be shared in a formal manner, and leveraging its value through reuse.

Through a supportive organizational climate and modern information technology, an organization can bring its entire organizational memory and knowledge to bear upon any problem anywhere in the world and at any time. For organizational success, knowledge, as a form of capital, must be exchangeable among persons, and it must be able to grow. Knowledge about how problems are solved can be captured, so that knowledge management can promote organizational learning, leading to further knowledge creation.

In the information technology context, knowledge is very distinct from data and information (see Figure 1). Whereas data are a collection of facts, measurements, and statistics, information is organized or processed data that are timely (i.e., inferences from the data are drawn within the time frame of applicability) and accurate (i.e., with regard to the original data) (Holsapple, 2003).'

The goal of knowledge management is for an organization to be aware of individual and collective knowledge so that it may make the most effective use of the knowledge it has (Bennet and Bennet, 2003). Historically, MIS has focused on capturing, storing, managing, and reporting explicit knowledge. Organizations now recognize the need to integrate both explicit and tacit knowledge in formal information systems. Knowledge management systems (KMSs) refers to the use of modern information technologies (e.g., the Internet, intranets, extranets, LotusNotes, software filters, agents, data warehouses) to systematize, enhance, and expedite intra- and interfirm knowledge management (Alavi and Leidner, 1999).

Knowledge management is more a methodology applied to business practices than a technology or product. Nevertheless, information technology is crucial to the success of every knowledge management system. Information technology enables KM by providing the enterprise architecture on which it is built.

\section{Research Hypotheses}

A hypothesis is a theorem that holds a relation between two phrases which can be either concepts or phenomena. Thus, hypothesis is a temporary theorem or a speculation that needs to be verified. (Kivi and Campenhood, 2009) In other words, hypothesis is a smart conjecture for solving the problem. Hypothesis can be defined as a notional relation between two or several variables which have been expressed in the form of verifiable phrases. (Danaeifard, et al, 2009)

This research includes a major hypothesis and 6 derivative hypotheses:

Major hypothesis:

The supports provided by information technology infrastructures (network and human resources) for establishment of knowledge management (knowledge creation, sharing and application) are above the average level in Communications Company of Sistan \& Balouchestan Province.

Derivative Hypotheses: 
1. The supports provided by the network for knowledge creation are above the average level.

2. The supports provided by the network for knowledge sharing are above the average level.

3. The supports provided by the network for knowledge application are above the average level.

4. The supports provided by the human resources for knowledge creation are above the average level.

5. The supports provided by the human resources for knowledge sharing are above the average level.

6. The supports provided by the human resources for knowledge application are above the average level.

The theoretical framework of this research is a conceptual model on how to propose theories concerning the relation between the affective parameters of the problem. Briefly speaking, conceptual framework indicates the mutual relations of variables. Designing a conceptual framework helps the researcher to analyze and verify certain relations in order to improve its knowledge about the viability of conditions. Consequently, verifiable hypotheses can be designed so as to determine whether the resulting theory is valid or not. (Danaeifard, et al, 2009)

\section{Research Methodology}

The research methodology is a descriptive-survey approach in this study. It is descriptive because it describes and interprets whatever exists in order to determine and depict the characteristics of variables in a certain condition (Danaeifard, et al, 2009).

It is also a survey-based approach because the researcher performs a kind of survey on a sample or the whole society so as to describe the attitudes, thoughts, behaviors, or characteristics of the studied population. (Danaeifard, et al, 2009). Many data gathering tools were applied in this research including questionnaires, observation, interview, information banks and computer network. (See Table 2)

After the confirmation of the questionnaire and corrections by the supervising professor, justifiability and perpetuity of the questionnaire was examined. The reliability coefficient was calculated using Cronbach's Alpha utilizing SPSS software. (See Table 3)

\section{Data Analysis}

Following the formulation of the research problem and determining the methodology and suitable data acquisition tools, the researcher is going to analyze the gathered data in order to verify the research hypotheses which are merely some probable and uncertain statements. A set of rules should be observed and relevant statistical techniques must be selected for data analysis and converting them into information by which the hypotheses can be verified. (Danaeifard, et al, 2009) For verifying the major hypothesis of the research, statistical test of Spearman correlation coefficient was used. For this purpose, the correlation coefficient was calculated between the total grades of information technology infrastructures and grades of establishment of knowledge management. The results of these calculations were obtained through output of SPSS software as indicated in Table 4 and 5.

The results of above table prove the fact that there is a positive and significant relation between grades of information technology infrastructures (network and human resources) and those of establishment of knowledge management (knowledge creation, sharing and application) in Communications Company of Sistan \& Baluchestan Province.

\section{Conclusions and Recommendations}

Knowledge management is a systemic topic, a subject whose successful implementation requires a comprehensive and thorough perspective towards different organizational factors. Many organizations intending to establish the knowledge management have invested in the field of information technology. IT is a constituent of knowledge management because its infrastructures play an essential role in establishment of knowledge management in an organization. This paper was intended to investigate the information technology infrastructures and their relation with components of knowledge management (knowledge creation, sharing and application) in Communications Company of Sistan \& Baluchestan Province. According to the result of Spearman correlation test, there is a positive and significant relation between information technology infrastructures (network and human resources) and components of knowledge management (knowledge creation, sharing (transfer) and application). Based on the analysis obtained from the gathered data, the recommendations of the current research are presented as follows:

1. More attention shall be paid to the software and their applications; also, complementary and advanced workshops shall be conducted for the personnel in order to enhance their scientific level and applicability of the software. 
2. Assigning authority to employees concerning the manner of doing their responsibility must be improved

3. The employees shall be encouraged to educate and learn from each other.

4. Company's knowledge shall be shared by other organizations through networking.

5. Collective sessions shall be regularly held for interchanging the ideas and comments of employees.

6. Using suitable hardware and software, the access to organization's knowledge base shall be facilitated for the individuals.

7. The employees shall be further enabled to access their needed information, documents and credentials.

\section{References}

Alavi, M. and Leidner, D. (1999). Knowledge Management Systems: Emerging Views and Practices from the Field, Maui: Proceedings of $32^{\text {nd }}$ Annual HICSS, HI, January.

Alavi, M. and Leidner, D.E. (2001). Review: knowledge management and knowledge management systems: conceptual foundations and research issues, MIS Quarterly, 25(1), 36-107. doi:10.2307/3250961, http://dx.doi.org/10.2307/3250961.

Allee, V. (1997). Twelve principles of knowledge management. Journal of Training \& Development, 51(11), 4-71.

Amar, A.D. (2004). Motivating knowledge Workers to innovate: a Model integrating Motivation dynamics and antecedents. European Journal of Innovation Management, 7(2), 89-101. doi:10.1108/14601060410534366, http://dx.doi.org/10.1108/14601060410534366.

Bennet, A. and Bennet, D. (2003). The Partnership-between Organizational Learning and Knowledge Management. Handbook on Knowledge Management, 1, New York: Springer-Verlag, 439-460.

Bhatt, G. (2001). Knowledge management in organizations: examining the interaction between technologies. techniques, and people. Journal of Knowledge Management, 5(1), 68-75. doi:10.1108/13673270110384419, http://dx.doi.org/10.1108/13673270110384419.

Cruz, N.M., Pe'rez, V.M., Cantero, C.T. (2009). The Influence of Employee Motivation on Knowledge Transfer. Journal of Knowledge Management, 13(6), 478-490. doi:10.1108/13673270910997132, http://dx.doi.org/10.1108/13673270910997132.

Coakes, E., Amar, A.D. and Granados, M.L. (2010). Knowledge Management, Strategy, and Technology: a Global Snapshot. Journal of Enterprise Information Management, 23(3), 282-304. doi:10.1108/17410391011036076, http://dx.doi.org/10.1108/17410391011036076.

Davenport, T.H. and Prusak, L. (1998). Working Knowledge: How Organizations Manage What They Know, Boston: Harvard Business School Press, MA.

Danaeifard, H., Alvani, S.M., Azar, A. (2009). Quantitative research methodology in management: a comprehensive approach, Tehran, Iran: Saffar Press.

Gupta, B., Iyer, L.S. and Aronson, J.E. (2000). Knowledge management: practices and challenges. Industrial Management \& Data Systems, 100(1), 17-21. doi:10.1108/02635570010273018, http://dx.doi.org/10.1108/02635570010273018.

Holm, J. (2001). Capturing the spirit of knowledge management. paper presented at the American Conference on Information Systems, Boston, MA, 3-5.

Horwitch, M. and Armacost, R. (2002). Helping knowledge management be all it can be. Journal of Business Strategy, 23(3), 26-32. doi:10.1108/eb040247, http://dx.doi.org/10.1108/eb040247.

Hauschild, S., Licht, T. and Stein, W. (2001). Creating a knowledge culture. The McKinsey Quarterly, 1, 74-81.

Hislop, D. (2003). Linking Human Resource Management and Knowledge Management via Commitment, Employees Relations, 25(2), 182-202. doi:10.1108/01425450310456479, http://dx.doi.org/10.1108/01425450310456479.

Holsapple, C. W. (2003). Knowledge and its Attributes, (1rd Ed.). In Handbook on Knowledge Management, New York: Springer-Verlag, pp. 165-188.

Kivi, Rymon and Campenhood, Luc Van. (2009). Research Methodology in Social Sciences, Translated by Abdulhossein Nick Gohar, Tehran, Iran: Totia Press. 
McInerney, C. (2002). Knowledge Management and the Dynamic Nature of Knowledge, Journal of the American Society for Information Science and Technology, 53(12), 1009-1018. doi:10.1002/asi.10109, http://dx.doi.org/10.1002/asi.10109.

Ouintas, P., Lefrere, P. and Jones, G. (1997), Knowledge management: a strategic agenda, Long Range Planning, 30(3), 91-385.

Singh, S.K. (2008). Role of Leadership in Knowledge Management: a Study. Journal of Knowledge Management, 12(4), 3-15. doi:10.1108/13673270810884219, http://dx.doi.org/10.1108/13673270810884219.

Voelpel, S. C. and Han, Z. (2005). Managing Knowledge Sharing in China: The Case of Siemens ShareNet, Journal of Knowledge Management, 9(3), 51-63. doi:10.1108/13673270510602764, http://dx.doi.org/10.1108/13673270510602764.

Table 1. Definition of knowledge management

\begin{tabular}{|l|l|}
\hline Author & Definition of knowledge management \\
\hline Ouintas et al. (1997) & $\begin{array}{l}\text { KM is to discover, develop, utilize, deliver, and absorb knowledge inside } \\
\text { and outside the organization through an appropriate management process } \\
\text { to meet current and future needs }\end{array}$ \\
\hline $\begin{array}{l}\text { Allee (1997) } \\
\text { Alavenport (1998) and Leidner (2001) }\end{array}$ & $\begin{array}{l}\text { KM is managing the corporation's knowledge through a systematically } \\
\text { and organizationally specified process for acquiring, organizing, } \\
\text { sustaining, applying, sharing and renewing both the tacit and explicit } \\
\text { knowledge of employees to enhance organizational performance and } \\
\text { create value }\end{array}$ \\
\hline Gupta et al. (2000) & $\begin{array}{l}\text { KM is a process that helps organizations find, select, organize, } \\
\text { disseminate, and transfer important information and expertise necessary } \\
\text { for activities }\end{array}$ \\
\hline Bhatt (2001) & $\begin{array}{l}\text { KM is a process of knowledge creation, validation, presentation, } \\
\text { distribution and application }\end{array}$ \\
\hline Horwitch and Armacost (2002) & $\begin{array}{l}\text { KM is getting the right information to the right people at the right time, } \\
\text { helping people create knowledge and sharing and acting on information } \\
\text { knowledge and information in } \\
\text { order to design better policy, modify action and deliver results }\end{array}$ \\
\hline
\end{tabular}


Table 2. Structure of Questionnaire Questions

\begin{tabular}{|c|c|c|}
\hline \multirow{2}{*}{$\begin{array}{c}\text { Components of Information } \\
\text { Technology }\end{array}$} & Investigated Variables & $\begin{array}{c}\text { Number of } \\
\text { Questions }\end{array}$ \\
\cline { 2 - 3 } & Human resource & 7 \\
\hline $\begin{array}{c}\text { Components of Knowledge } \\
\text { Management }\end{array}$ & Knowledge Creation & 8 \\
\cline { 2 - 3 } & Knowledge Sharing & 6 \\
\cline { 2 - 3 } & Knowledge Application & 6 \\
\hline
\end{tabular}

Table 3. Reliability Cofficient

\begin{tabular}{|c|c|}
\hline N of Item & Cronbach's alpha \\
\hline 34 & 0.940 \\
\hline
\end{tabular}

Table 4. Results of correlation coefficient for major hypothesis

\begin{tabular}{|c|c|c|}
\hline Variables & Statistical Indices & $\begin{array}{c}\text { Grades of Information } \\
\text { Technology Infrastructures }\end{array}$ \\
\hline \multirow{2}{*}{$\begin{array}{c}\text { Information Technology } \\
\text { Infrastructures }\end{array}$} & Spearman Correlation & 1 \\
\cline { 2 - 3 } & Significance level (Sig) & 0 \\
\cline { 2 - 3 } & Frequency & 240 \\
\hline \multirow{2}{*}{$\begin{array}{c}\text { Establishment of Knowledge } \\
\text { Management }\end{array}$} & Spearman Correlation & $0.890 \mathrm{a}$ \\
\cline { 2 - 3 } & Significance level (Sig) & 0.000 \\
\cline { 2 - 3 } & Frequency & 240 \\
\hline
\end{tabular}

a: correlation is significant in 0.01

Table 5. Results of derivative hypotheses

\begin{tabular}{|c|c|c|c|c|c|}
\hline $\begin{array}{l}\text { Derivative } \\
\text { hypotheses }\end{array}$ & Variables & $\begin{array}{c}\text { Spearman Correlation } \\
\text { Coefficient }\end{array}$ & Sig & Frequency & Test Result \\
\hline 1 & $\begin{array}{c}\text { Network and Knowledge } \\
\text { Creation }\end{array}$ & 0.406 & 0.000 & 240 & $\mathrm{H} 0$ rejected \\
\hline 2 & $\begin{array}{c}\text { Network and Knowledge } \\
\text { Sharing }\end{array}$ & 0.520 & 0.000 & 240 & H0 rejected \\
\hline 3 & $\begin{array}{l}\text { Human resources and } \\
\text { Knowledge Application }\end{array}$ & 0.691 & 0.000 & 240 & H0 rejected \\
\hline 4 & $\begin{array}{l}\text { Human resources and } \\
\text { Knowledge Creation }\end{array}$ & 0.904 & 0.000 & 240 & H0 rejected \\
\hline 5 & $\begin{array}{c}\text { Human resources and } \\
\text { Knowledge Sharing }\end{array}$ & 0.957 & 0.000 & 240 & H0 rejected \\
\hline 6 & $\begin{array}{l}\text { Human resources and } \\
\text { Knowledge Application }\end{array}$ & 0.916 & 0.000 & 240 & H0 rejected \\
\hline
\end{tabular}




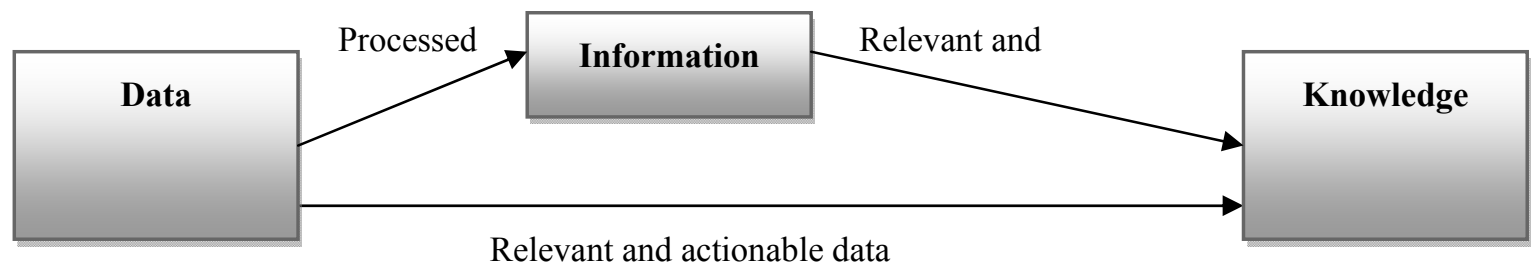

Figure 1. Data, Information and Knowledge 